\title{
Validation and development of an immunonephelometric assay for the determination of alpha- 1 antitrypsin levels in dried blood spots from patients with COPD*
}

\author{
Desenvolvimento e validação de um método de imunonefelometria em \\ amostras de sangue em papel-filtro para a dosagem da alfa- 1 antitripsina \\ em pacientes com DPOC
}

\author{
Laura Russo Zillmer, Rodrigo Russo, Beatriz Martins Manzano, lvan lvanaga, \\ Oliver Augusto Nascimento, Altay Alves Lino de Souza, Gildo Santos Júnior, \\ Francisco Rodriguez, Marc Miravitlles, José Roberto Jardim
}

\begin{abstract}
Objective: To validate and develop an immunonephelometric assay for the determination of alpha- 1 antitrypsin (AAT) levels in dried blood spots from COPD patients in Brazil. Methods: We determined AAT levels in serum samples and dried blood spots from 192 COPD patients. For the preparation of dried blood spots, a disk (diameter, $6 \mathrm{~mm}$ ) was placed into a tube, eluted with $200 \mu \mathrm{L}$ of PBS, and stored overnight at $4^{\circ} \mathrm{C}$. All of the samples were analyzed by immunonephelometry in duplicate. We used the bootstrap resampling method in order to determine a cut-off point for AAT levels in dried blood spots. Results: The correlation coefficient between the AAT levels in serum samples and those in dried blood spots was $r=0.45$. For dried blood spots, the cut-off value was 2.02 $\mathrm{mg} / \mathrm{dL}$ ( $97 \% \mathrm{Cl}: 1.45-2.64 \mathrm{mg} / \mathrm{dL}$ ), with a sensitivity, specificity, positive predictive value, and negative predictive value of 100\%, 95.7\%, 27.2\%, and 100\%, respectively. Conclusions: This method for the determination of AAT levels in dried blood spots appears to be a reliable screening tool for patients with AAT deficiency.
\end{abstract}

Keywords: alpha 1-antitrypsin deficiency; Nephelometry and turbidimetry; Pulmonary disease, chronic obstructive.

\section{Resumo}

Objetivo: Validar e desenvolver um método de dosagem de alfa-1 antitripsina (AAT) por imunonefelometria em amostras de sangue em papel-filtro em pacientes com DPOC no Brasil. Métodos: Amostras de soro e de sangue em papel-filtro de 192 pacientes com DPOC foram utilizadas para a dosagem de AAT. Para a preparação das amostras de sangue em papel-filtro, um disco do papel com diâmetro de $6 \mathrm{~mm}$ foi colocado em um tubo e eluído com $200 \mu \mathrm{L}$ de PBS, permanecendo por toda a noite a $4^{\circ} \mathrm{C}$. Todas as amostras foram analisadas em duplicata por imunonefelometria. 0 método de reamostragem bootstrap foi utilizado para a determinação de um ponto de corte para o nível de AAT nas amostras de sangue em papel-filtro. Resultados: 0 coeficiente de correlação entre os níveis de AAT em soro e em sangue em papel-filtro foi de $r=0,45$. Para as amostras em papel-filtro, $o$ ponto de corte foi de 2,02 mg/dL (1C97\%: 1,45-2,64 mg/dL), com sensibilidade, especificidade, valor preditivo positivo e valor preditivo negativo de 100\%, 95,7\%, 27,2\% e 100\%, respectivamente. Conclusões: Este método de determinação dos níveis de AAT em sangue em papel-filtro se mostrou uma ferramenta confiável para o rastreamento de pacientes com deficiência de AAT.

Descritores: Deficiência de alfa 1-antitripsina; Nefelometria e turbidimetria; Doença pulmonar obstrutiva crônica.

\footnotetext{
* Study carried out at the Pulmonary Rehabilitation Center, Universidade Federal de São Paulo/Escola Paulista de Medicina UNIFESP/EPM, Federal University of São Paulo/Paulista School of Medicine - in the Department of Molecular Biology, Afip Laboratory; and at the Institute of Psychology, Federal University of São Paulo, São Paulo, Brazil; as well as in the Departments of Biochemistry and Pulmonology, Vall d'Hebron University Hospital, Barcelona, Spain.

Correspondence to: José Roberto Jardim. Rua Botucatu, 740, $3^{\circ}$ andar, Pneumologia UNIFESP/EPM, CEP 04021-032, São Paulo, SP, Brasil. Tel. 5511 5572-4301.E-mail: jardimpneumo@gmail.com

Financial support: This study received financial support from the Fundação de Amparo à Pesquisa do Estado de São Paulo (FAPESP, São Paulo Research Foundation). Laura R Zillmer was the recipient of a master's scholarship grant from the Coordenação de Aperfeiçoamento de Pessoal de Nível Superior (CAPES, Office for the Advancement of Higher Education). Rodrigo Russo was the recipient of a doctoral grant from the Fundação de Amparo à Pesquisa do Estado de São Paulo (FAPESP, São Paulo Research Foundation). Submitted: 23 July 2013. Accepted, after review: 19 August 2013.
} 


\section{Introduction}

Alpha- 1 antitrypsin (AAT) deficiency is an autosomal codominant genetic disorder resulting from mutations in the SERPINA 1 gene, which encodes the synthesis of the AAT protein. ${ }^{(1)}$ It is characterized by a reduction in circulating plasma AAT levels and is associated with an increased risk for early pulmonary emphysema, ${ }^{(2)}$ as well as for liver disease and panniculitis. ${ }^{(3)}$

Once considered a rare disease, AAT deficiency is a highly prevalent genetic condition, according to current epidemiological data, although it is frequently underdiagnosed in clinical practice. (3-5) Estimates from studies conducted in eight countries (Canada, the Netherlands, Spain, the United Kingdom, Sweden, New Zealand, and Australia) show that only $0.41 \%$ and $0.35 \%$ of individuals with the PiZZ phenotype and the SS phenotype, respectively, had been identified. ${ }^{(6)}$ In Brazil, there are no epidemiological data on the prevalence of AAT deficiency or the frequency of deficiency alleles. ${ }^{(7)}$

Recent recommendations from the World Health Organization, the American Thoracic Society, and the European Respiratory Society advocate the use of assays for the quantitative determination of plasma AAT concentrations, especially in patients with COPD, liver disease of unknown etiology, necrotizing panniculitis, bronchiectasis of unknown etiology, or a family history of liver disease, necrotizing panniculitis, COPD, and bronchiectasis. ${ }^{(8,9)}$ Early diagnosis is essential to the prognosis of individuals with AAT deficiency, given that the natural history of pulmonary involvement is directly affected by potentially modifiable environmental factors, such as smoking. ${ }^{(10,11)}$

The diagnosis of AAT deficiency is based on the quantitative determination of serum AAT levels, as well as on phenotyping, genotyping, or both. ${ }^{(12,13)}$ One of the problems for conducting screening programs is that of blood handling and transportation. The implementation of a dried blood spot method would make it possible to use it in population programs, because it is a minimally invasive method, sample storage is easy, and it allows sample transportation from different regions to the central laboratory, with no need for complex and costly methods of sample preservation. ${ }^{(9,14)}$ In addition, these samples can also be used for phenotyping and genotyping, if necessary. ${ }^{(13,15)}$ In Brazil, no dried blood spot method for the determination of AAT levels has been developed, and few laboratories can determine serum AAT levels. Considering the landmass of Brazil, it is important that a dried blood spot method be implemented in the country.

Therefore, the objective of the present study was to develop and validate an immunonephelometric assay for the determination of AAT levels in dried blood spots from COPD patients in Brazil.

\section{Methods}

This was a cross-sectional study evaluating COPD patients recruited from the COPD Outpatient Clinic of the Federal University of São Paulo Pulmonary Rehabilitation Center between July and September of 2011.

The inclusion criteria were as follows: having been diagnosed with COPD in accordance with the criteria established by the European Respiratory Society-i.e., having an $\mathrm{FEV}_{1} / \mathrm{FVC}$ less than $88 \%$ predicted (males) or less than 89\% predicted (females) after bronchodilator use ${ }^{(16)}$; having been clinically stable in the last six weeks ${ }^{(17)}$; and being 40 years of age or older. Patients with a previous diagnosis of AAT deficiency were excluded from the study, as were those with clinical symptoms of asthma and those with any non-pulmonary inflammatory or infectious process leading to increased serum AAT concentrations.

All patients gave written informed consent. The determination of AAT levels was performed at the Centro de Diagnóstico Brasil (Brazil Diagnostic Center), located in the city of São Paulo. The present study was approved by the Research Ethics Committee of the Federal University of São Paulo Hospital São Paulo (Protocol no. 0633/10).

All study participants had recently undergone spirometry (less than one year previously) with a portable spirometer (Easy One ${ }^{\circledR}$; NDD Medical Technologies, Chelmsford, MA, USA, and Zurich, Switzerland). The reference values used to calculate percentage of predicted values were based on the reference standards of the Third National Health and Nutrition Examination Survey. ${ }^{(18)}$

After analysis of the spirometry results and application of the inclusion and exclusion criteria, the patients underwent blood sample collection using two methods: blood was drawn from the cubital vein into a tube containing EDTA and centrifuged at 3,200 rpm for $30 \mathrm{~min}$, with the serum being separated and stored at $-20^{\circ} \mathrm{C}$; and a drop of peripheral blood, obtained by 
pricking the distal region of one of the fingers, was placed on a filter paper card (Whatman 903, lot W101; Whatman/GE Healthcare, Florham Park, NJ, USA); the filter paper card was dried in room air for $12 \mathrm{~h}$ and then stored at $-20^{\circ} \mathrm{C}$ until the time of analysis. ${ }^{(19)}$

For the analysis of dried blood spots, the filter paper cards were cut into disks (diameter, $6 \mathrm{~mm}$ ) and the disks were placed into Eppendorf tubes, to which $200 \mu \mathrm{L}$ of PBS were added. This solution remained at $4^{\circ} \mathrm{C}$ for $12 \mathrm{~h}$ overnight. On the following day, the disks were removed from the solution and, subsequently, the samples were centrifuged at 3,200 rpm for $30 \mathrm{~min}$ in order to separate the disk residues (solid part) from the liquid part of the samples, which is called eluate. The serum was thawed and centrifuged at 3,200 rpm for $30 \mathrm{~min}$. Serum and eluate samples were analyzed on a Siemens BNIl system (Siemens Healthcare, Indianapolis, IN, USA).

The system was calibrated with the $\mathrm{N}$ Protein Standard SL (Nephelometry; Siemens Healthcare). The calibration curves were tested at different dilutions $(1: 160 ; 1: 80 ; 1: 40 ; 1: 20$; $1: 10$; and 1:5). The margin of deviation from the standard protein and the value obtained were accepted within a range of +5 to -5 . In addition, daily checks with the standard SL were carried out at different AAT concentrations: low (101.0 mg/dL); medium (159.0 mg/dL); and high $(231.0 \mathrm{mg} / \mathrm{dL})$.

The analysis of AAT concentrations was performed using the $\mathrm{N}$-antiserum, which is a liquid animal serum produced by immunization of rabbits with highly purified human AAT (Siemens Healthcare).

Eluate and serum samples were placed into 5-mL acrylic tubes and analyzed by immunonephelometry. This method is characterized by the emission of an intense beam of light over a sample containing immune complexes between the AAT protein and anti-AAT antibodies. The beam of light, upon contact with this immune complex, is reflected and collected by a photometer, the intensity of the reflected radiation being proportional to the amount of antigen-antibody present in the sample. Serum samples are automatically diluted by the system at a ratio of $1: 20$, which is the concentration required to achieve antigen-antibody equilibrium. However, dried blood spots contain much lower serum levels, making dilution unnecessary $(1: 1)$, as reported in previous studies. ${ }^{(19,20)}$

The statistical analysis was performed with the Statistical Package for the Social Sciences, version 18.0 for Windows (SPSS Inc, Chicago, IL, USA). Continuous variables are expressed as mean and standard deviation, and categorical variables are expressed as percentage. Pearson's correlation coefficient was used to investigate the association between two parametric variables, namely, serum AAT values obtained in duplicate, AAT values in eluates, measured in duplicate; and serum AAT values relative to AAT values in eluates.

We used the bootstrap resampling method in order to determine a cut-off point and a confidence interval of 97\% for dried blood spots. This method consists of a resampling technique, through which data from the actual sample (the study sample) are randomly selected (with $\mathrm{N}-1$ ) for observation and confidence intervals are generated for each calculated value. The sample is randomly selected 1,000 times, and 1,000 models are made for each of these $\mathrm{N}-1$ samples, increasing the power of the sample in cases of small samples and improving the estimators of confidence when the sample distribution is unknown or when the population distribution is unknown. The cut-off point for dried blood spots was also characterized in terms of sensitivity, specificity, positive predictive value (PPV), and negative predictive value (NPV).

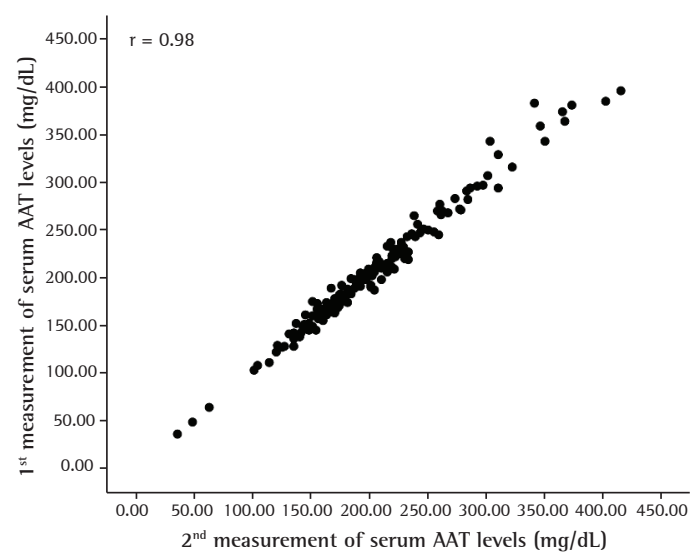

Figure $\mathbf{1}$ - Correlation between the duplicate measurements of serum alpha-1 antitrypsin (AAT) levels $(\mathrm{N}=192)$. 

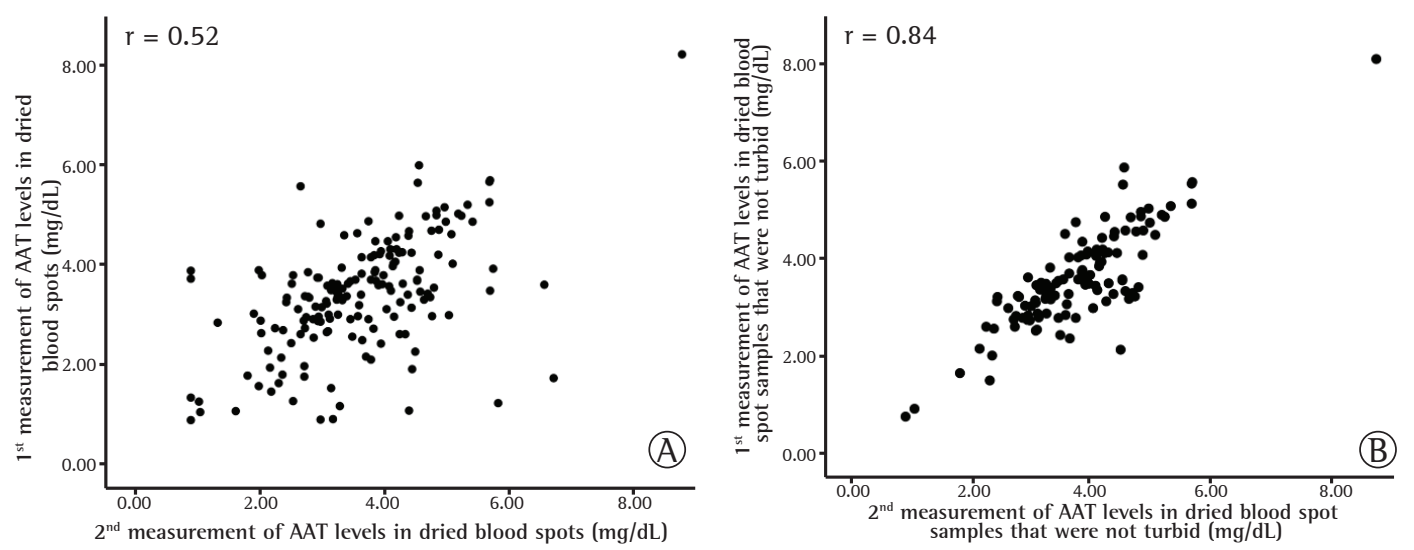

Figure 2 - In A, correlation between the duplicate measurements of alpha-1 antitrypsin (AAT) levels in eluates from dried blood spots $(N=192)$. In $B$, correlation between the duplicate measurements of AAT levels in eluates from dried blood spot samples that were not turbid $(n=116)$.

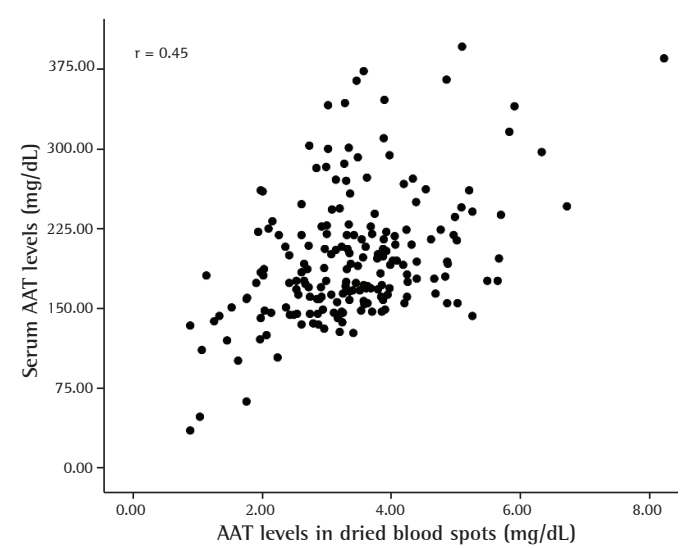

Figure 3 - Correlation between the measurements of serum alpha-1 antitrypsin (AAT) levels and the measurements of AAT levels in eluates from dried blood spots $(\mathrm{n}=192)$.

\section{Results}

A total of 240 patients were contacted over the three-month study period. However, only 192 patients met the eligibility criteria. Of the 48 individuals who were excluded, 17 had exacerbations, 18 did not meet the spirometry criteria for COPD, 5 showed a bronchodilator response and had a history consistent with asthma, 3 had bronchiectasis, 2 had pulmonary sarcoidosis, 2 had lung cancer, and 1 had sequelae of pulmonary tuberculosis.

The demographic data of the study participants are described in Table 1. There were no significant gender-related differences. The mean age of the study population was $68.5 \pm 9.6$ years. The individuals were predominantly White.
The spirometry results are described in Table 1, and, as expected for COPD patients, the values for percentage of predicted $\mathrm{FEV}_{1} / \mathrm{FVC}$ and percentage of predicted FEV $_{1}$ characterized obstructive lung disease.

To test sample reproducibility, AAT levels in serum and in eluates from dried blood spots were determined in duplicate. Figure 1 shows the correlation between the duplicate measurements of serum AAT levels $(r=0.98)$, and Figure 2A shows the correlation between the duplicate measurements of AAT levels in eluates from dried blood spots $(r=0.52)$.

Some eluate samples were turbid in one of the duplicate measurements performed, affecting the AAT value obtained and causing disparity between the duplicate measurements of the same sample. Therefore, we performed a second correlation analysis of the duplicate measurement results of eluates from dried blood spot samples that were not turbid $(n=116)$. The second analysis showed a correlation of $r$ $=0.84$ (Figure 2B). However, none of the three patients with AAT deficiency, as determined by the measurement of serum AAT levels, a method considered to be the gold standard, were included in this analysis, because one of the duplicate samples was turbid.

For the analysis of correlation between the serum AAT levels and the AAT levels in eluates from dried blood spots, we selected one of the serum AAT values and one of the AAT values in eluate samples that were not turbid. The observed correlation was $r=0.45$ (Figure 3). 
To determine the sensitivity and specificity of the eluate method, we used the bootstrap resampling method, comparing the AAT values measured in serum (gold standard) with those measured in eluates from dried blood spots, so as to determine a cut-off point for AAT values in eluates; the value obtained was $2.02 \mathrm{mg} / \mathrm{dL}$ (97\% Cl: 1.45-2.64). The values for sensitivity, specificity, PPV, and NPV of the AAT values in eluates from dried blood spots are shown in Table 2. All three patients with AAT deficiency in our sample had AAT levels below $1.80 \mathrm{mg} /$ $\mathrm{dL}(62.6 \mathrm{mg} / \mathrm{dL}$ in serum); the two values $(2.02$ $\mathrm{mg} / \mathrm{dL}$ and $2.64 \mathrm{mg} / \mathrm{dL}$ ) had a sensitivity and NPV of $100 \%$. With the cut-off point of 2.02 $\mathrm{mg} / \mathrm{dL}, 14$ of the 192 patients in our sample would have to undergo determination of serum AAT levels for establishing the diagnosis of AAT

Table 1 - Demographic characteristics of the sample $(\mathrm{N}=192){ }^{\mathrm{a}}$

\begin{tabular}{lc}
\hline Characteristic & Result \\
\hline Gender & \\
$\quad$ Female & $105(54.7)$ \\
$\quad$ Male & $87(45.3)$ \\
Age, years ${ }^{\mathrm{b}}$ & $65.8 \pm 9.6$ \\
Race & \\
$\quad$ White & $157(81.8)$ \\
$\quad$ Non-White & $35(18.2)$ \\
Spirometry & \\
Absolute FEV $/$ FVC & \\
FEV $/$ FVC, \% of predicted & $0.47 \pm 0.10$ \\
FVC, L & $62.4 \pm 14.4$ \\
FVC, $\%$ of predicted $_{\text {FEV }}, \mathrm{L}$ & $2.64 \pm 0.77$ \\
FEV $_{1}, \%$ of predicted & $82.4 \pm 19.9$ \\
\hline
\end{tabular}

a Values expressed as $n(\%)$, except where otherwise

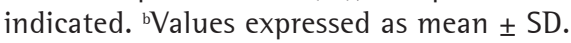

Table 2 - Sensitivity, specificity, positive predictive value, and negative predictive value of cut-off points calculated by using the bootstrap resampling technique. ${ }^{a}$

\begin{tabular}{lccc}
\hline Variable & \multicolumn{3}{c}{ Cut-off point } \\
\cline { 2 - 4 } & Obtained & Minimum & \\
& 2.02 & 1.45 & 2.64 \\
\hline Sensitivity & $100.0 \%$ & $66.6 \%$ & $100.0 \%$ \\
Specificity & $95.7 \%$ & $98.9 \%$ & $86.7 \%$ \\
Positive & $27.2 \%$ & $50.0 \%$ & $10.7 \%$ \\
predictive value & & & \\
Negative & $100.0 \%$ & $99.4 \%$ & $100.0 \%$ \\
predictive value & & & \\
\hline
\end{tabular}

${ }^{\mathrm{a}}$ At the $97 \% \mathrm{Cl}$. deficiency in 3 patients. However, with the value of $2.64 \mathrm{mg} / \mathrm{dL}, 32$ patients would have to undergo determination of serum AAT levels for establishing this diagnosis also in 3 patients.

\section{Discussion}

The objective of the present study was to develop and validate an immunonephelometric assay for the determination of AAT levels in eluates from dried blood spots in patients with COPD. We chose to create a confidence interval starting at the cut-off point determined by the bootstrap resampling method, evaluating the sensitivity and specificity of the values and their effect on clinical choices for screening new patients.

The quantitative determination of serum AAT levels is recommended for the diagnosis of AAT deficiency. ${ }^{(9)}$ However, this test in not performed in most Brazilian cities; handling, storage, transportation, and costs make its largescale use unfeasible. Therefore, analysis of dried blood spots by immunonephelometry becomes an attractive option in terms of accessibility, ${ }^{(21)}$ given that the samples can be mailed to a central laboratory from anywhere in Brazil. ${ }^{(22)}$ In the present study, the dried blood spot samples were frozen at $-20^{\circ} \mathrm{C}$, because they were not analyzed immediately after collection. However, dried blood spot samples can be maintained in room air for one week, as well as in temperatures of $4{ }^{\circ} \mathrm{C}$ and $-20^{\circ} \mathrm{C}$ for four weeks. ${ }^{(19)}$

The results of duplicate measurements of serum AAT levels were highly reproducible $(r=$ 0.98), which shows excellent sample stability. The correlation between the serum AAT levels and the AAT levels in dried blood spots was low $(r=$ 0.45), suggesting that the AAT values measured in dried blood spots cannot be quantitatively compared with those measured in serum. This finding differs from those reported by some authors, who observed a good correlation between the determination of AAT levels in dried blood spots and the determination of serum AAT levels. Wencker et al. validated an immunonephelometric assay in 427 patients with lung disease and found an excellent correlation between the values measured in dried blood spots and those measured in serum $(r=0.95)$, with no false-negative or false-positive results. ${ }^{(22)}$ The findings corroborate those of Costa et al., who obtained a good correlation between 500 serum and dried blood spot samples $\left(\mathrm{r}^{2}\right.$ $=0.86) .{ }^{(19)}$ However, those authors emphasize 
that, although the two techniques have a good correlation, the dried blood spot method is a semiquantitative rather than a quantitative method, being appropriate for screening, on the basis of a cut-off point, providing positive or negative results for the presence of the AAT protein. One group of Italian researchers also validated a dried blood spot method in comparison with the standard serum method in 149 patients who had low or very low serum AAT levels (0.16-0.53 g/L) and in individuals who had intermediate or normal AAT levels $(0.54-2.93 \mathrm{~g} / \mathrm{L})$. The correlation coefficients of the two groups were $r^{2}=0.98$ and $r^{2}=0.90$, respectively. ${ }^{(20)}$ However, those authors did not analyze their results in terms of PPV or NPV for the evaluation of sensitivity and specificity.

The fact that there is recognized variation in immunonephelometric assays led us to calculate a confidence interval, obtaining the minimum and maximum values in relation to the cut-off point. To determine this interval, we used the bootstrap resampling method, because the population of individuals with AAT deficiency was small. This analysis made it possible to increase the sample power, because the calculation was repeated 1,000 times, establishing a cut-off point of $2.02 \mathrm{mg} / \mathrm{dL}$ and making the $97 \%$ confidence interval more accurate $(1.45-2.64 \mathrm{mg} / \mathrm{dL})$. On the basis of these results, we evaluated the sensitivity, specificity, PPV, and NPV of the cut-off point established through this type of sampling (Table 2). For the cut-off point of $2.02 \mathrm{mg} / \mathrm{dL}$ obtained for dried blood spots, we found a sensitivity and specificity of 100\% and 95.7\%, respectively, with a PPV and NPV of $27.2 \%$ and $100 \%$, respectively. By using the maximum value in the confidence interval, it is possible that no patient with AAT deficiency will be identified as normal. After a detailed review of the literature, we found no studies reporting confidence interval values for AAT levels in dried blood spots.

To Kwon \& Farrell, screening tests should be highly sensitive, because this characteristic reduces the probability of an individual having a false-negative result. False-negative results are the major concern in screening tests, because individuals will probably be identified only when they start having symptoms, which sometimes occurs late in the disease, compromising prognosis. (23) Conversely, the establishment of a higher cut-off point so that all cases with deficiency can be detected will result in a larger number of false-positive results. The disadvantage of false-positive results in the detection of AAT deficiency is evident, because a larger number of serum tests will be conducted. ${ }^{(24)}$ However, it must be borne in mind that the process of screening new patients for AAT deficiency should begin with screening tests rather than end with them.

Regarding the cut-off point for dried blood spots for screening patients for AAT deficiency, we found two studies in the literature that have reported different values. One study, which evaluated 300 patients with COPD and 200 healthy individuals, observed that all patients with AAT deficiency had values below $1.8 \mathrm{mg} / \mathrm{dL}$ in dried blood spots, which was equivalent to a serum concentration of $100 \mathrm{mg} / \mathrm{dL} .{ }^{(19)}$ After that study, two groups of authors adopted the same cut-off point as that suggested by Costa et al. ${ }^{(19)}$ and found that dry blood spot tests produced no false-positive or false-negative results when compared with genetic tests, showing that the value established in that study was highly accurate. ${ }^{(15,22)} \ln 2006$, Gorrini et al. evaluated 114 patients and established a cut-off point of $1.13 \mathrm{~g} / \mathrm{L}$ for dried blood spots, with a sensitivity and specificity of 0.92 and 0.90 , respectively. ${ }^{(20)}$ These values are similar to those reported in the present study; however, the cut-off point stipulated in the present study was considerably higher, because we decided to adopt a sensitivity of 100\%, greatly reducing the possibility of false-negative results.

The immunonephelometric assay for the determination of AAT levels in dried blood spots that was developed in the present study showed a moderate correlation $(r=0.54)$ between the duplicate measurements of the same sample. However, some samples were turbid in one of the duplicate measurements, a factor that reduces light reflection at the time of analysis and consequently reduces AAT levels, which could have directly affected the correlation of the duplicate dried blood spots. A sub-analysis only of the duplicate measurements of samples that were not turbid revealed a good correlation $(r=0.84)$. This sub-analysis did not include any patients with AAT deficiency, which means that this finding may not be representative for the population of individuals with AAT deficiency. There are no published studies in the literature that have addressed the reproducibility between serum samples and dried blood spots or the effect 
of sample turbidity, but this finding suggests that samples that are turbid should be interpreted with caution.

We conclude that the use of dried blood spots is an excellent option for screening patients for AAT deficiency, because this method had high sensitivity and specificity, as well as a low PPV and NPV. However, the values obtained by this method cannot be quantitatively compared with serum AAT values. We believe that it is mandatory to choose the maximum value in the confidence interval in order to minimize falsenegative diagnoses. Therefore, the dried blood spot method is an attractive solution to the current state of underdiagnosis of AAT deficiency in Brazil, because it enables rapid, efficient, and minimally invasive screening in the diagnosis of this deficiency at a low cost. Further studies investigating the prevalence of AAT deficiency are needed in order to implement specific programs for the treatment and management of this condition.

\section{Acknowledgments}

We would like to thank the Laboratório Centro de Diagnóstico Brasil (Brazil Diagnostic Center Laboratory) for the determinations of AAT levels. We would also like to thank the Brazilian Association of Patients with Alpha-1 Antitrypsin Deficiency for making it possible for Dr. Gildo Santos Júnior to go to Italy to learn the method for the determination of AAT levels in dried blood spots with Dr. llaria Ferraroti and Dr. Maurizio Luizetti.

\section{References}

1. Riva A, Kohane 1S. SNPper: retrieval and analysis of human SNPs. Bioinformatics. 2002;18(12):1681-5. http://dx.doi.org/10.1093/bioinformatics/18.12.1681

2. Tomashefski JF Jr, Crystal RG, Wiedemann HP, Mascha E, Stoller JK; Alpha 1-Antitrypsin Deficiency Registry Study Group. The bronchopulmonary pathology of alpha-1 antitrypsin (AAT) deficiency: findings of the Death Review Committee of the national registry for individuals with Severe Deficiency of Alpha-1 Antitrypsin. Hum Pathol. 2004;35(12):1452-61. http://dx.doi.org/10.1016/j. humpath.2004.08.013 PMid:15619203

3. Stoller JK, Aboussouan LS. Alpha1-antitrypsin deficiency. Lancet. 2005;365(9478):2225-36. http://dx.doi. org/10.1016/S0140-6736(05)66781-5

4. Lieberman J, Winter B, Sastre A. Alpha 1-antitrypsin Pi-types in 965 COPD patients. Chest. 1986;89(3):370-3. http://dx.doi.org/10.1378/chest.89.3.370 PMid:3485034

5. Stoller JK, Sandhaus RA, Turino G, Dickson R, Rodgers K, Strange C. Delay in diagnosis of alpha1-antitrypsin deficiency: a continuing problem. Chest. 2005;128(4):1989-94. http:// dx.doi.org/10.1378/chest.128.4.1989 PMid:16236846

6. Luisetti M, Seersholm N. Alpha1-antitrypsin deficiency. 1: epidemiology of alpha 1-antitrypsin deficiency. Thorax. 2004;59(2):164-9. http://dx.doi.org/10.1136/ thorax.2003.006494 PMid:14760160 PMCid:PMC1746939

7. Camelier AA, Winter DH, Jardim JR, Barboza CE, Cukier A, Miravitlles M. Alpha-1 antitrypsin deficiency: diagnosis and treatment. J Bras Pneumol. 2008;34(7):514-27. http://dx.doi.org/10.1590/S1806-37132008000700012 PMid:18695797

8. Alpha 1-antitrypsin deficiency: memorandum from a WHO meeting. Bull World Health Organ. 1997;75(5):397415. PMid:9447774 PMCid:PMC2487011

9. American Thoracic Society; European Respiratory Society. American Thoracic Society/European Respiratory Society statement: standards for the diagnosis and management of individuals with alpha- 1 antitrypsin deficiency. Am J Respir Crit Care Med. 2003;168(7):818-900. http:// dx.doi.org/10.1164/rccm.168.7.818 PMid:14522813

10. Piitulainen E, Eriksson S. Decline in FEV1 related to smoking status in individuals with severe alpha 1-antitrypsin deficiency (PiZZ). Eur Respir J. 1999;13(2):247-51. http:// dx.doi.org/10.1183/09031936.99.13224799

11. Tobin MJ, Cook PJ, Hutchison DC. Alpha 1 antitrypsin deficiency: the clinical and physiological features of pulmonary emphysema in subjects homozygous for $\mathrm{Pi}$ type Z. A survey by the British Thoracic Association. $\mathrm{Br}$ J Dis Chest. 1983;77(1):14-27. http://dx.doi. org/10.1016/0007-0971(83)90002-5

12. Snyder MR, Katzmann JA, Butz ML, Wiley C, Yang P, Dawson DB, et al. Diagnosis of alpha-1-antitrypsin deficiency: An algorithm of quantification, genotyping, and phenotyping. Clin Chem. 2006;52(12):2236-42. Erratum in: Clin Chem. 2007;53(9):1724. http://dx.doi. org/10.1373/clinchem.2006.072991 PMid:17053153

13. Ferrarotti 1, Scabini R, Campo 1, Ottaviani S, Zorzetto M, Gorrini M, et al. Laboratory diagnosis of alpha 1antitrypsin deficiency. Transl Res. 2007;150(5):267-74. Erratum in: Transl Res. 2008;151(4):232. http://dx.doi. org/10.1016/j.trsl.2007.08.001 PMid:17964515

14. de la Roza C, Costa X, Vidal R, Vilá S, Rodríguez-Frías F, Jardí R, et al. Screening program for alpha-1 antitrypsin deficiency in patients with chronic obstructive pulmonary disease, using dried blood spots on filter paper [Article in Spanish]. Arch Bronconeumol. 2003;39(1):8-12. http:// dx.doi.org/10.1157/13042412 PMid:12550013

15. Rodriguez F, Jardí R, Costa X, Cotrina M, Galimany R, Vidal R, et al. Rapid screening for alpha1-antitrypsin deficiency in patients with chronic obstructive pulmonary disease using dried blood specimens. Am J Respir Crit Care Med. 2002;166(6):814-7. http://dx.doi.org/10.1164/ rccm.2203025 PMid:12231490

16. Qaseem A, Snow V, Shekelle P, Sherif K, Wilt TJ, Weinberger $\mathrm{S}$, et al. Diagnosis and management of stable chronic obstructive pulmonary disease: a clinical practice guideline from the American College of Physicians. Ann Intern Med. 200;147(9):633-8.

17. Cazzola M, MacNee W, Martinez FJ, Rabe KF, Franciosi LG, Barnes PJ, et al. Outcomes for COPD pharmacological trials: from lung function to biomarkers. Eur Respir J. 2008;31(2):416-69. http://dx.doi. org/10.1183/09031936.00099306 PMid:18238951

18. Hankinson JL, Odencrantz JR, Fedan KB. Spirometric reference values from a sample of the general U.S. 
population. Am J Respir Crit Care Med. 1999;159(1):17987. http://dx.doi.org/10.1164/ajrccm.159.1.9712108 PMid:9872837

19. Costa X, Jardi R, Rodriguez F, Miravitlles M, Cotrina M, Gonzalez C, et al. Simple method for alpha1-antitrypsin deficiency screening by use of dried blood spot specimens. Eur Respir J. 2000;15(6):1111-5. http://dx.doi.org/10.1034/ j.1399-3003.2000.01521.x PMid:10885432

20. Gorrini M, Ferrarotti 1, Lupi A, Bosoni T, Mazzola P, Scabini R, et al. Validation of a rapid, simple method to measure alpha1-antitrypsin in human dried blood spots. Clin Chem. 2006;52(5):899-901. http://dx.doi. org/10.1373/clinchem.2005.062059 PMid:16638961

21. Vidal R, Blanco I, Casas F, Jardí R, Miravitlles M; Committee on the National Registry of Individuals with Alpha-1 Antitrypsin Deficiency. Guidelines for the diagnosis and management of alpha-1 antitrypsin deficiency [Article in Spanish]. Arch Bronconeumol. 2006;42(12):645-59. http://dx.doi.org/10.1016/S1579-2129(07)60007-X

22. Wencker M, Marx A, Konietzko N, Schaefer B, Campbell EJ. Screening for alpha 1-Pi deficiency in patients with lung diseases. Eur Respir J. 2002;20(2):319-24. http://dx.doi. org/10.1183/09031936.02.02012001 PMid:12212962

23. Kwon C, Farrell PM. The magnitude and challenge of false-positive newborn screening test results. Arch Pediatr Adolesc Med. 2000;154(7):714-8. http://dx.doi. org/10.1001/archpedi.154.7.714

24. Benkendorf J, Goodspeed T, Watson MS. Newborn screening residual dried blood spot use for newborn screening quality improvement. Genet Med. 2010;12(12 Suppl):S269-72. http://dx.doi.org/10.1097/GIM.0b013e3181 fea489 PMid:21150375

\section{About the authors}

\section{Laura Russo Zillmer}

Research Physical Therapist. Pulmonary Rehabilitation Center, Department of Pulmonology, Universidade Federal de São Paulo/ Escola Paulista de Medicina - UNIFESP/EPM, Federal University of São Paulo/Paulista School of Medicine - São Paulo, Brazil.

\section{Rodrigo Russo}

Research Physician. Pulmonary Rehabilitation Center, Department of Pulmonology, Universidade Federal de São Paulo/Escola Paulista de Medicina - UNIFESP/EPM, Federal University of São Paulo/Paulista School of Medicine - São Paulo, Brazil.

\section{Beatriz Martins Manzano}

Research Physical Therapist. Pulmonary Rehabilitation Center, Department of Pulmonology, Universidade Federal de São Paulo/ Escola Paulista de Medicina - UNIFESP/EPM, Federal University of São Paulo/Paulista School of Medicine - São Paulo, Brazil.

\section{Ivan Ivanaga}

Research Physical Therapist. Pulmonary Rehabilitation Center, Department of Pulmonology, Universidade Federal de São Paulo/ Escola Paulista de Medicina - UNIFESP/EPM, Federal University of São Paulo/Paulista School of Medicine - São Paulo, Brazil.

\section{Oliver Augusto Nascimento}

Attending Physician. Department of Pulmonology, Universidade Federal de São Paulo/Escola Paulista de Medicina - UNIFESP/ EPM, Federal University of São Paulo/Paulista School of Medicine - São Paulo, Brazil.

\section{Altay Alves Lino de Souza}

Researcher. Department of Psychobiology, Universidade Federal de São Paulo/Escola Paulista de Medicina - UNIFESP/EPM, Federal University of São Paulo/Paulista School of Medicine - São Paulo, Brazil.

\section{Gildo Santos Júnior}

Biomedical Professional. Department of Molecular Biology, Afip Laboratory, São Paulo, Brazil.

\section{Francisco Rodriguez}

Researcher. Departments of Biochemistry and Pulmonology, Vall d'Hebron University Hospital, Barcelona, Spain.

\section{Marc Miravitlles}

Researcher. Departments of Biochemistry and Pulmonology, Vall d'Hebron University Hospital, Barcelona, Spain.

\section{José Roberto Jardim}

Tenured Professor. Department of Pulmonology, Universidade Federal de São Paulo/Escola Paulista de Medicina - UNIFESP/EPM, Federal University of São Paulo/Paulista School of Medicine - São Paulo, Brazil. 